\title{
Sprawozdanie z prac w Instytucie Józefa Piłsudskiego w Londynie w 2018 r.
}

W dniach 17 listopada - 14 grudnia 2018 r. po raz kolejny przebywałem w Instytucie Józefa Piłsudskiego w Londynie. Podczas pobytu uporządkowane zostały dwie kolekcje: nr 107 Archiwum Bohdana Podoskiego oraz nr 146 Instytut Józefa Piłsudskiego w Londynie (która zawiera również akta Wydziału Studiów tegoż Instytutu, wcześniej osobny numer 145).

Kolekcja B. Podoskiego, polityka i parlamentarzysty okresu międzywojnia, współtwórcy konstytucji kwietniowej, zawiera po uporządkowaniu 37 j.a. (0,3 mb). Pośród archiwaliów znajdują się w niej dokumenty i listy osobiste, wspomnienia wojenne, korespondencja związana z działalnością publiczną, pisma dotyczące sprawy rozbicia i zjednoczenia emigracji politycznej w Londynie. Szczególnie te ostatnie zagadnienia są licznie reprezentowane w omawianym zbiorze. Oprócz wymienionych rodzajów dokumentów można w nim znaleźć wystąpienia i opracowania B. Podoskiego, innych autorów oraz wycinki prasowe i wydawnictwa emigracyjne. W ramach kolekcji utworzono kilka serii porządkujących układ zbioru: dokumenty osobiste, związane z okresem II wojny, materiały dotyczące emigracji politycznej w Wielkiej Brytanii, opracowania i wystąpienia oraz wydawnictwa, druki, prasa i wycinki prasowe.

Druga z kolekcji - Instytut Józefa Piłsudskiego w Londynie (nr 146) obejmuje, jak wspomniano, część do niedawna osobnej kolekcji (nr 145) Wydział Studiów Instytutu. Po uporządkowaniu liczy 44 j.a. (ok. 0,5 mb). Przede wszystkim są tam materiały dotyczące działalności naukowej Instytutu, relacje, wspomnienia i opracowania. Oprócz głównych tematów, którymi zajmuje się Instytut, związanych z odzyskaniem przez Polskę niepodległości i jego patronem Józefem Piłsudskim, pojawiają się zagadnienia odnoszące się do dwudziestolecia międzywojennego. W zbiorze znaleźć można także materiały dotyczące sytuacji powojennej w Polsce i analizy działalności antykomunistycznej w Polsce i na świecie. Znajduje się w nim również dokumentacja spraw organizacyjnych Instytutu, spraw osobowych, protokoły z posiedzeń Rady Instytutu i Wydziału Studiów, uchwały Rady Instytutu, korespondencja oraz sprawozdania finansowe. Ponadto są tam materiały pokazujące reakcję Instytutu na niektóre opracowania i wystąpienia historyczne pozostające w zakresie jego badań. Dla lepszej orientacji w kolekcji wydzielono w niej kilka serii: sprawy organizacyjne i osobowe, działalność Instytutu i Wydział Studiów, materiały do historii Instytutu, sprawy krajowe po II wojnie światowej, opracowania oraz wspomnienia, ulotki i wycinki prasowe.

Obydwie kolekcje zostały przepakowane do pudeł litych bezkwasowych, teczek i koszulek bezkwasowych. Jedna z nich (nr 107) jest już dostępna na stronie Instytutu: http:// www.pilsudski.org.uk/pl/katalog.php. Niebawem powinna zostać udostępniona druga $\mathrm{z}$ uporządkowanych kolekcji (nr 146). 
W Instytucie nadal użytkowana jest baza IZA, z której sukcesywnie przenosi się rekordy do bazy danych użytkowanej zarówno przez Instytut Piłsudskiego w Ameryce, jak i w Londynie. Baza ta umożliwia podpinanie skanów do poszczególnych j.a. Baza IZA pozbawiona jest już wsparcia z Polski, gdyż nie jest już w kraju użytkowana. Powoduje to zakłócenia w jej obsłudze, w tym w pobieraniu danych.

W Instytucie przechowywanych jest wiele kolekcji, które nie posiadają dokładnego inwentarza, z ważniejszych nadal nieopracowany pozostaje zbiór poświęcony Józefowi Beckowi (nr 20). Niezbędne są dalsze prace porządkowe

Oprócz prac archiwalnych podczas pobytu w Instytucie przeprowadzona została lekcja historii dla uczniów sobotniej szkoły polskiej z Amersham poświęcona odzyskaniu przez Polskę niepodległości.

Sylwester Rękas Archiwum Narodowe w Krakowie 